DEVELOPING ENGLISH READING MATERIAL FOR THE ELEVENTH GRADE STUDENTS OF SOFTWARE ENGINEERING PROGRAM

IN SMK NEGERI BINAAN PROVINSI

SUMATERA UTARA MEDAN

AN ARTICLE

Submitted in Partial Fulfillment of the Requirements for the Degree of Sarjana Pendidikan

By

BENEDICK DEO AGATHA

Registration Number: 2133121014

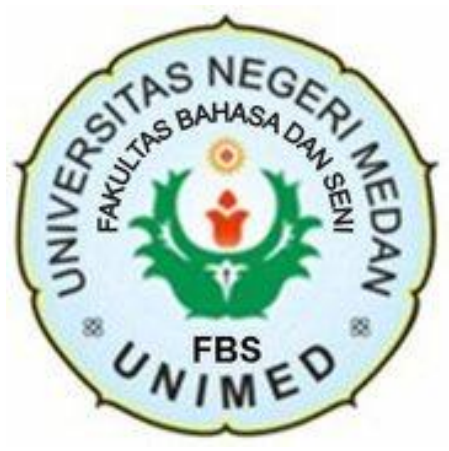

ENGLISH AND LITERATURE DEPARTMENT

FACULTY OF LANGUAGES AND ARTS

STATE UNIVERSITY OF MEDAN

2017 


\begin{abstract}
ÁrTicile
Developing Engiish Reading Miateriai for the Eieventh Grade Students of Software Engineering Program in SMK Negeri

Binaañ Provinsi Sumatera Utara Meưan

Disusun dan Diajukan oleh:

B̉enedick L̉eo Ágatha

NIM 2133121014
\end{abstract}

Teiah diverifíkasi dan dỉnyatakan memenuhi syarat

untuk diunggah pada jurnal online

İiedan, N้ovember $20 \mathrm{i} 7$

Menyetujui

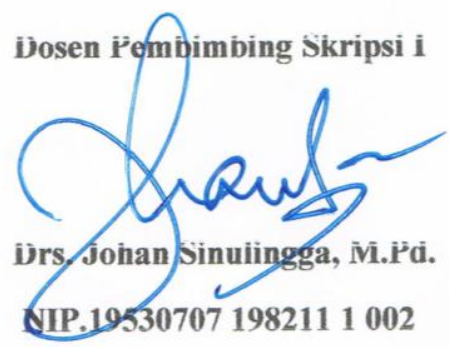

iosen P̌embimbing Skrripsi ii

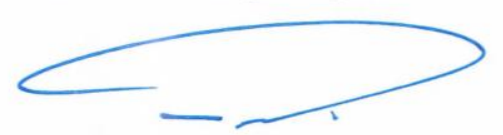

Dra. İasitowarni Siregar, Mi.Ė.

NIP.19671102 1993032001

K̄etua P̌rodii P̉endiđiikan B̉ahasa inggris

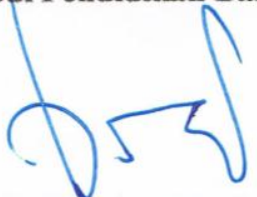

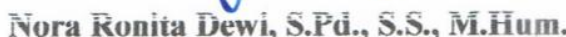

NIP. 198005222008132003 


\title{
DEVELOPING ENGLISH READING MATERIAL FOR THE ELEVENTH GRADE STUDENTS OF SOFTWARE ENGINEERING PROGRAM IN SMK NEGERI BINAAN PROVINSI SUMATERA UTARA MEDAN
}

\author{
*Benedick Deo Agatha \\ ** Johan Sinulingga \\ **Masitowarni Siregar
}

This study is aimed to design English Reading Material needed for students of Software Engineering Program and develop English Reading Material for Grade XI students of Software Engineering Program in SMK Negeri Binaan Provinsi Sumatera Utara Medan. This research was conducted by Research and Development (R \& D) design through six stages; 1) Gathering Data and Information, 2) Analyzing data, 3) Designing new material, 4) Validated new material by the experts, 5) Revising reading material, 6) Final Project. The subject of this research was class XI-RPL 1 students of Software Engineering program consisting of 29 students. The instrumentations for collecting the data were questionnaire and interview. After, anlyzing the data, the researcher got the students' needs. The data were gathered by administering interview and distributing the questionnaire to 29 respondents to get the students'needs. The interview and questionnaire results prove that the students need English reading materials which cointain English for Software Engineering program. Thus , developing English reading mateials were procedure text. Then, the procedure texts related to their study program. The products have been validated by experts. The average scores are 4,2 from English Lecturer and 4,3 from English Teacher.It means the developing materials categorized as relevant or appropriate for Grade XI Students of Software Engineering Program.

Keywords : Research and Development $(R \& D)$, reading material, procedure text, Software Engineering Program

\footnotetext{
*Graduate Status

**Lecturer Status
} 


\section{INTRODUCTION}

\section{Background of the study}

Education can be defined as a way to improve students' knowledge, by having good students are expected to be able earn their life through a good occupation or being professional worker in the future. In Indonesia education system, there are many subjects that student need to understand such as: Physics, Mathematics, Chemistry, Biology, Economic, Sociology, History, English, and other else. Those subjects have been taught since the students were in Junior High School until Senior High School. By studying those subjects the students are expected to can increase their knowledge and information.

Another fact that shows up, there is also level of education that focus one skill named Vocational High School or in Indonesia called Sekolah Menengah Kejuruan (SMK). This level of this education prepared the students to having a career or job based on the specific applied skills. That is the purpose of vocational high school and why they are specified. To achieve this purpose a vocational high school gives a learning experience and adequate exercise to build a professional capability in science and technology through specific programs. For example a student's of vocational high school in Culinary Study Program will get many subject related to food and beverage and students of vocational high school in Software Engineering Study Program will get many subject related to software itself.

In the globalization era now days the need of development in engineering, technicians are not only expected to have technical competences in accordance to their specialization but also are expected to have a good communication skill in 
international language just like English. As CIA stated that English is a commonly language that uses in the world (2011) with total 56 countries that officially use it and 328.000.000 people around the world. To master English is a must for technician, especially engineering because their clients may come from other countries whose languages are English. Beside that many instruction of engineering use English.

Now days many people consider that English is an important subject to be learned because it is common used in every field such as science, international relationship, etc, and of course software engineering. By seeing some advantage people try to master this international language. BSNP (Badan Standar Nasional Pendidikan) (2010:10) states that English course aims to equip students in improving their abilities to understand English text from academic purposes and specific purposes.

There are four competences in English and reading plays an important role to the English Language Teaching (ELT) to develop the creative side of people. This statement is supported by Harsono $(2007 ; 5)$. Harsono stated that reading material is one of the very crucial elements that have to exist to conduct teaching / learning activities. English reading material is required in order to improve reading skill of students.

For that reason, to facilitate the needs of students to improve their reading skill especially for procedure text material, the reading material in the text book should be appropriate with the students' capacity in order to maximize their capability in comprehending the texts. To develop of teaching material for vocational students must be appropriate or based on what they need and it will be 
easier to reach the goal of that teaching and learning process because of the fulfillment of their necessity about English to support their vocational purposes. Beside material for reading, newmaterial needs to develop to them.

\section{REVIEW OF LITERATURE}

Reading is the ability to understand words contained in a document and make use of the knowledge for personal growth and development (Dadzie, 2008). This implies making meaning out of recorded information either printed or nonprinted in the life of an individual. People read for different reasons and purposes, some of which include for pleasure, leisure, relaxation, information and for knowledge.

Ian Sommerville in his book Software Engineering (2011) explain that software engineering is an engineering discipline that is concerned with all aspects of software production that deal with software specification, software development software validation, and software evolution. Further, in this book shown up the differences between software engineering and computer science which is computer science focuses on theory and fundamentals; software engineering is concerned with the practicalities of developing and delivering useful software.

Hutchinson and Waters (1987) attempts to define ESP, that is, rather than a product, ESP is an approach-meaning that it involves no particular type of language teaching material or methodology. According to those researchers, the core questionof ESP should be: "why does this learner need to learn a foreign language?" The mainelement of learning English is the 'purpose' why the learner 
is learning the language. They state' ESP is an approach to language teaching in which all decisions as content and method are based on the learner's reasons for learning.'(Hutchinson and Waters, 1987:19) In reference to Hutchinson and Water's definition, Antony (1997)suggests that their definition has validity but has some weak points. He notes that since various non-specialist ESP teachers utilize an ESP approach in their syllabi are based upon learner needs analysis and their own specialist personal knowledge of English for real communication, it is never clear where ESP courses finish and General English courses start. Robinson (1991) suggests a definition that ESP rises upon two important criteria, which are:

$\square$ ESP is normally 'goal-directed'

$\square$ A needs analysis, which specifies what students have to do exactly (through the medium of English), should be applied to develop ESP courses.

Simply learning material can be defined as any material used by the teacher and students for teaching and learning process. In order to achieve the objective of teaching and learning itself, Fathurahman and Sutikno (2007) states that learning material is medium to achieve the objective of teaching and learning which consumed by the students. And Arikunto ( 1990) in Fathurahman and Sutikno (2007) add Fathuhrahman and Sutikno (2007) says that learning material is the essence in the process of teaching and learning which must be mastered by the students.

Tomlinson (1998) states that material development refers to anything which is done by writers, teachers or learners to provide sources of language input and to exploit those sources in ways which maximize the likelihood intake : in 
other words, supplying of information about and or experience of language in ways designed to promote language learning.

\section{RESEARCH METHODOLOGY}

\section{A. Research Design}

This study applied educational Research and Development (R\&D) research method. Borg and Gall (2003:569) stated that the educational R\&D is an industrybased development model in which findings of research are used to design new products and procedures, which were systematically field-tested, evaluated, and refined until they meet specified criteria of effectiveness, quality or similar standards. This developmental research consist of six stages, as mentioned below:

1. Gathering information and data

2. Analyzing data

3. Designing new materials

4. Validating new materials by experts

5. Revising reading materials

6. Final product

The subject of this study was the students of the eleventh grade students of SMK Negeri Binaan Provinsi Sumatera Utara Medan ( class XI-1). This subject was chosen because the reading material in the school were not appropriate to the students' need. "Effective Communication" published by Erlangga Publisher in 2008use by the students, which basically it was implemented specifically for vocational high school students 


\section{Techniques of Analysis Data}

The researcher were identified the main variables such as : Target need and need analysis are needed of the students of SMK Negeri Binaan Provinsi Sumatera Utara Medan. The data was obtained from questionnaires is firstly collected and analyze. This data was needed to evaluate the reading material and assess the students' need of English. The quantitative data was analyzed by using percentage and descriptive analysis. The data was firstly collected in the table, and then the researcher described the findings. The qualitative data was analyzed by drawing the conclusion of the questionnaires. So, based on the analyses, the researcher planned the recommended material especially in reading material for vocational school in Software Engineering Program.

\section{RESEARCH FINDINGS AND DATA ANALYSIS}

Data Analysis:

The results of data analysis are presented. The fundamental goal achieved in this study are the students need the appropriate reading material and developing the reading material particularly procedure text for Grade XI Students of Software Engineering in SMK Negeri Binaan Provinsi Sumatera Utara, Medan.

1. Gathering Information and Data: (Existing materials and Syllabus )

2. Analyzing Data

a. Existing Material

Table 4.1 Students' Responses to the Existing Procedure Text Material

\begin{tabular}{|c|c|c|}
\hline No. Procedure Text & $\begin{array}{c}\text { As students of software } \\
\text { engineering program, } \\
\text { Do you need those } \\
\text { procedure texts? }\end{array}$ & $\begin{array}{l}\text { Are those procedure } \\
\text { texts related to your } \\
\text { major, software } \\
\text { engineering? }\end{array}$ \\
\hline
\end{tabular}




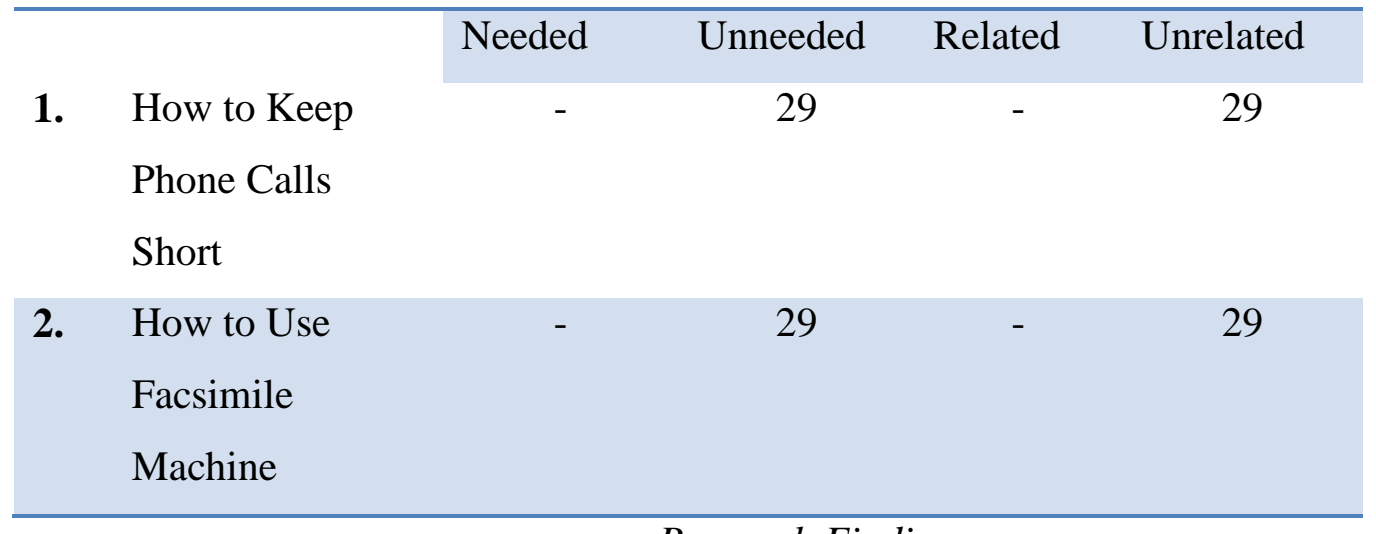

b. Need Analysis

\section{Research Findings}

1. Questionnaire Analysis

From the questionnaire administered, the researcher can identify. Generally, the students want English learning which makes them able to master both general structures and software engineering program terms. The reading texts given also should be accompanied by pictures. Furthermore, the students of software engineering program, they want the texts talked about both the common knowledge and knowledge of software engineering program. They want the English texts which not only increase their common knowledge but also can support their learning based on their major. So there must be equal number of both general texts and the texts of software engineering program given. It means that the reading texts of procedure provided to the students will support their learning process and also related to their major.

2. Interview Analysis

the questionnaire and interview administered to the students and English teacher of software engineering. The researcher can identify that the existing procedure text material were not appropriate to the students of software engineering program and also the existing material was not 
needed to the students. It caused the students become less motivation to read the texts. In other words, it was hard to the students in comprehending the material because they are not in secretary program because the material is appropriate to the secretary program. Thus, the results of the needs analysis were used by the researcher as guidance in developing appropriate procedure text material for reading skill.

3. Designing New Material

After administering the needs analysis, the appropriate procedure text material for reading skill to students of software engineering program in Grade XI were identified, the main point was the procedure text material given should relate to their study program. It was done not only to meet the students' needs in their learning process and also in their future job but also to make the students will be ease in comprehending the material so that the basic competence and indicator in syllabus could be achieved

4. Validating by The Experts

Table 4.5 English Lecturer's Validation Score

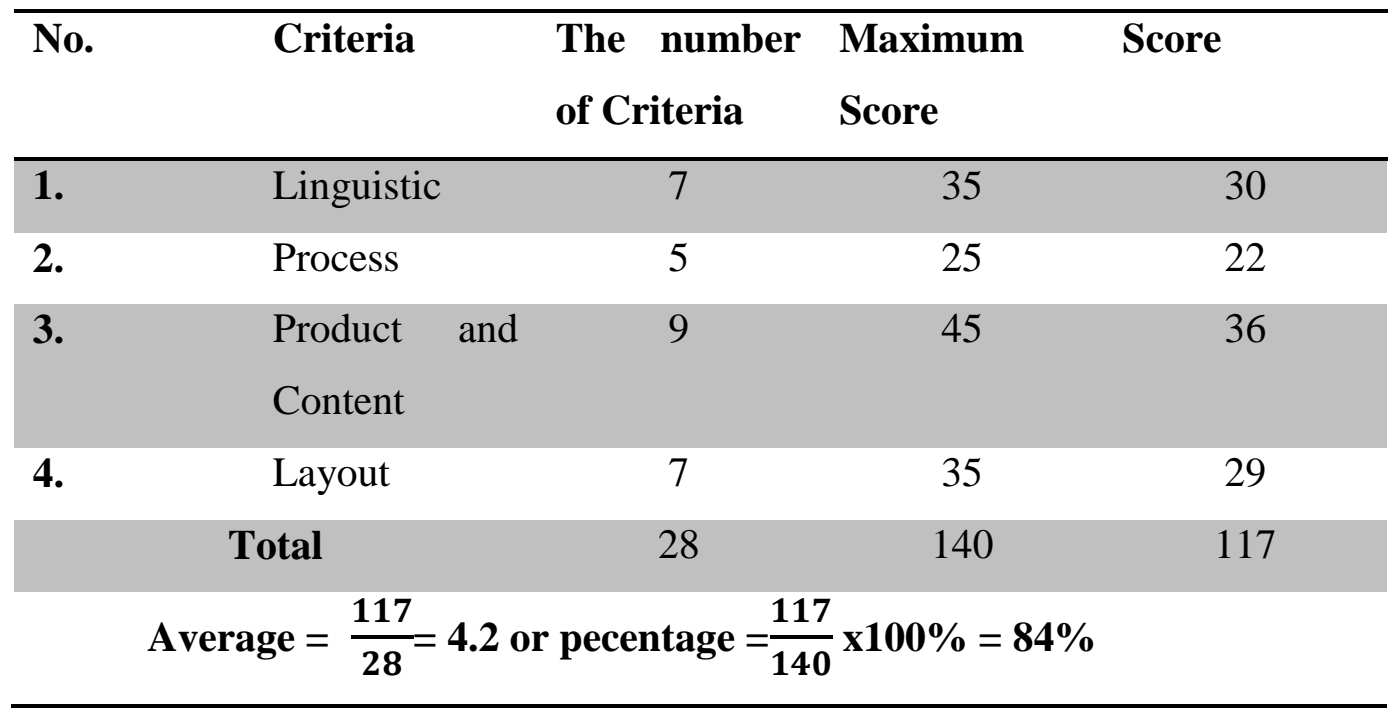


5. Revising Reading Material

1. English Lecturer's suggestions

As suggested by English Lecturer, the common text "How to Scan Your Computer Using SMADAV Antivirus" to something that more specific to software engineering program that was " How to Delete Partition in Windows"

6. Final Product

\section{How to Make "Hello World' By Using Java Script}

First, go to test site and create a new folder named 'scripts' (without the quotes). Then, within the new scripts folder that just created, create a new file called main.js. Save it in scripts folder.

Next, in index.html file enter the following element on a new line just before the closing </body $>$ tag:

$<$ scriptsrc $=$ "scripts/main.js" $></$ script $>$

This is basically doing the same job as the <link> element for CSS - it applies the JavaScript to the page, so it can have an effect on the HTML (along with the CSS, and anything else on the page).

Now add the following code to the main.js file:

varmyHeading=document.querySelector('h1'); myHeading.textContent='Hello world!';

Finally, make sure the HTML and JavaScript files are saved, then load index.html in the browser. You should see something like the following:

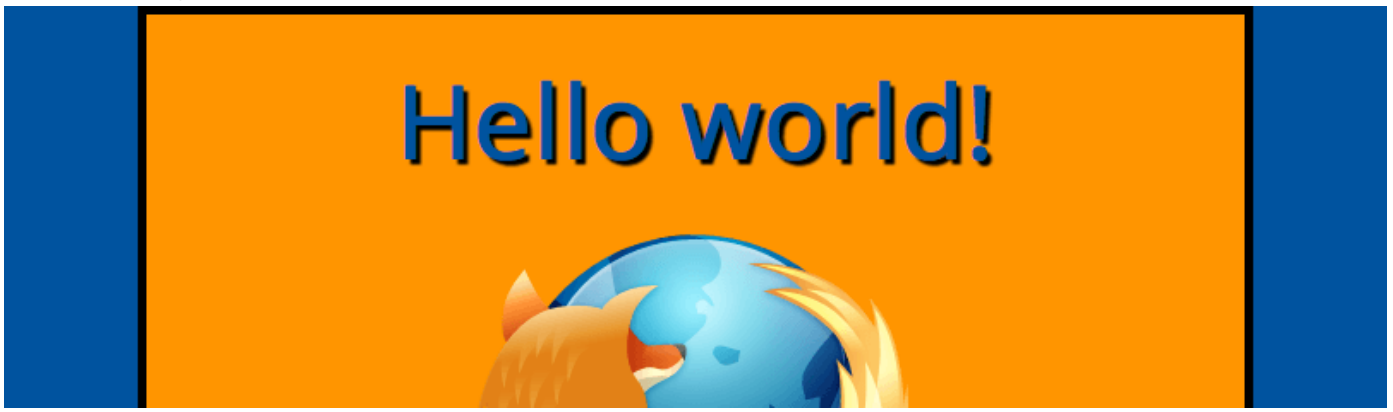




\section{CONCLUSIONS AND SUGGESTIONS}

\section{Conclusions}

The students of Software Engineering Program needed the specific material in reading text especially for procedure text. In this study, the problems were they studied procedure text but it was not appropriate to their major which must make the motivation for them in reading the material. From the acquired data and information were started by observation of the book that used in eleventh grade students of Software Engineering Program in SMK Negeri Binaan Provinsi Sumatera Utara Medan used "Effective Communication, An Integrated Course of English for Vocational High School" published by Pusat Perbukuan Departemen Pendidikan Nasional in 2008. They learned about How to Keep Phone Calls Short and How to Use Facsimile Machine.

The new reading material was developed by using six phases of Research and Developmental (R \& D), they were; 1) Gathrering Information and data, 2) Analyzing Data, 3) Designing Materials, 4) Validating by Experts, 5) Revising, and 6) Final Product. The material was developed based on the data of the students' needs analysis the questionnaire, the analysis of interview from the English teachers and the existing material.

Suggestion

\section{- Teacher}

In learning English for the vocational students, the teacher should find the specific material for the students. The learning process can be successfull if the teacher can give the materials related to the students' program and also The 
teacher can apply "English for Specific Purposes" approach to apply in teaching English.

\section{- $\quad$ Students}

The students must be active and wise if they want to increase their ability in reading English. If they can not find the specific material from the school especially their textbook, they should utilize the internet to find the specific material.

\section{- Institution}

In order to improve the ability of students you should use this developed material in learning process so the students will motivate. 


\section{REFERENCES}

Borg and Gall. 2003. Development Research. New York: Continuum.

Harsono,Y.M. (2007). Developing Learning Materials For Specific Purposes.TEFLIN Journal. Volume 18, Number 2.

Hermida, J. (2009). The Importance of Teaching Academic Reading Skills in First-Year University Courses. Canada : Algoma University.

Hutchinson, T and Waters, A.1989. English for Soecific Purposes: A learnining centered Approach. Cambridge: Cambridge University Pres

Sommerville, I. (2011). Software Engineering The $9^{\text {th }}$ Edition. Pearson Education Inc,

Septiani, F. (2014). DEVELOPING READING TEXT MATERIALS FOR VOCATIONAL SCHOOL. Indonesia : UNIMED Press.

Tomlinson, B. (ed.) (1998). Materials Development in Language Teaching. Cambridge: Cambridge University Press. 